\title{
Oldest reptile to leave UK?
}

\section{London}

THE ultimate fate of a unique British fossil hangs in the balance this week following a meeting last Friday of the Reviewing Committee on the Export of Works of Art, acting on behalf of the UK Department of Trade and Industry (DTI). The 338-million-year-old fossil, still not formally named, represents the earliest-known reptile and was described in Nature last week $(342,676-678$; 1989). The committee heard the case for delaying its sale to a museum in West Germany, but the verdict is still confidential; sources close to the committee expect that it will be announced later this week after consultation with the DTI and the Office of Arts and Libraries. British researchers are hopeful that the committee will recommend that the sale be delayed to give museums in Britain the chance to raise the money to keep the fossil in the UK.

The fossil was discovered in Lower Carboniferous limestones at East Kirkton in Lothian, Scotland, by Edinburgh-based professional collector Stanley Wood, who put the 10-inch specimen on the market at $£ 180,000$ exclusive of Value Added Tax. Researchers at the Royal Museum of Scotland and the Natural History Museum in London had expected a more modest sum, somewhere around $£ 40,000$, but the price tag exceeds their current budgets. A sale has now been agreed with the Natural History Museum in Stuttgart, where the fossil will find a home in the spring of 1990. Rupert Wild of the Stuttgart Museum was unavailable for comment on Monday.

The sale of any national treasure demands the scrutiny of the British government, who set down the conditions under which an export licence is granted. The committee has never before been required to judge the fate of a fossil, or indeed any other geological specimen. "This is the first time a fossil has become a work of art", said Beverley Halstead of Imperial College, London, one of the independent assessors called upon to advise the committee on the scientific importance of the find.

The committee's deliberations were consequently a new experience for British palaeontologists. In addition to Halstead, Dr Gilbert Larwood of the University of Durham and Professor Alec Panchen of the University of Newcastle upon Tyne advised the panel. Testimony was also submitted by Mr Wood, who was, he says, accorded "a very, very sympathetic hearing". Making the case for delaying the sale were Dr Robin Cocks, Keeper of Palaeontology at the Natural History Museum in London, his colleague Dr Angela Milner, and Dr Ian Rolfe, Keeper of Geology at the National Museums of Scotland.
Less measured, apparently, were the remarks of the committee's chairman, $\mathrm{Mr}$ Jonathan Scott, who was, in Halstead's words, "not at all pleased" that details of the matter had found their way into the British press. This broadside may have been directed at Rolfe, who in all innocence had allowed free discussion of the story in the belief that all relevant details — including the price tag — were public knowledge. Milner confirms that this information had been available in the Scottish press as long ago as 1 September, when articles in The Scotsman and the Glasgow Herald mentioned the possibility of the sale at the price now under discussion. The Herald even mentioned the Stuttgart Museum as a potential buyer. But the thing that may have angered Scott most, says Milner, was the presence outside the meeting of one of several press photographers who had hounded Wood on his way to the meeting.

The fossil concerns Rolfe particularly, because the Royal Scottish Museum already houses many fossils collected at East Kirkton. Rolfe, in common with all those involved, was not prepared to comment on the committee's decision at this stage, although it is clear that the committee cannot deny an export licence - the issue is simply whether the sale will be delayed.
This decision is based on a judgement of the object's worth according to rules established in 1952 known as the Waverley Criteria, in particular whether the loss of an object would constitute a national "misfortune", whether it has special aesthetic merit, or whether it is of significance to some branch of art, learning or history.

The second and third criteria were not at issue in this particular case. The first criterion was more contentious, because scientific research knows no boundaries; the fossil would, presumably, be as accessible to scholarship in Stuttgart as in Edinburgh, for example.

Wood is highly regarded in the palaeontological community for his almost magical ability to find interesting fossils in unexpected places, but his relationship with museums is sometimes compromised because of his treatment of fossils as objects for sale, not to mention his readiness to talk to the press. On the other hand, museum workers feel that many important fossils would remain undiscovered were it not for Wood's expertise. Wood has now left East Kirkton in search of pastures new - he spoke to Nature just before leaving for the Moray Firth, an area well-known for exposures of Devonian age. But he thinks that other fossil reptiles await discovery at East Kirkton: "there's no reason to suspect that there won't be", adds Milner. "There might be dozens more."

Henry Gee

\section{Japan and Taiwan refuse international ban}

\section{Sydney}

Several South Pacific nations agreed last month in Wellington, New Zealand, on a ban on drift-net fishing in their territorial seas and exclusive economic and fishing zones. The ban, which emerged from an international convention on the prohibition of fishing with long drift nets, also extends to fishing by any vessels flagged by the signatory countries in a prohibited area designated by the convention. But Japan and Taiwan, two of the biggest participants in what critics say is a destructive and

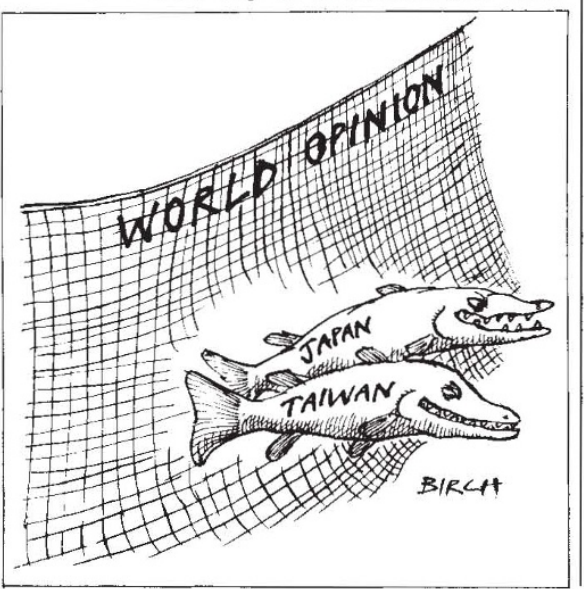

indiscriminate method of fishing (see Nature 342, 9; 1989), dropped out of the negotations and will not accede to the ban.

The vice-chairperson of the South Pacific conference, Jesse Raglmar of the Federated States of Micronesia, said that the convention would extend the ban over international waters to cover an area from French Polynesia to Australia, bounded by the Marshall Islands to the north. Although the convention has an enforcement clause allowing South Pacific nations to take "appropriate measures" to stop drift-net fishing in their own regions, any such measures attempted outside a country's exclusive economic zone would have to accord with international laws of the sea.

Japan's refusal to participate in the ban was expected. Taiwan withdrew its delegation from the conference after insisting that it should be given government status, despite its not being so recognized by a majority of signatory countries. A spokesperson for the Australian government's Department of Foreign Affairs and Trade said that by trying to secure a statement of support for its longstanding claim to be the real China, "Taiwan appears to be pushing a political objective unrelated to the conference".

Tania Ewing 